\title{
Correction to: Rootstock effects on seed yield and quality in watermelon
}

\author{
Mohamed Dhamir Kombo ${ }^{1,2} \cdot$ Nebahat Sari $^{2}$ \\ Published online: 24 January 2020 \\ (c) Korean Society for Horticultural Science 2020

\section{Correction to: \\ Horticulture, Environment, and Biotechnology (2019) 60:303-312 \\ https://doi.org/10.1007/s13580-019-00131-x}

The article, Rootstock effects on seed yield and quality in watermelon, written by Mohamed Dhamir Kombo and Nebahat Sari, was originally published electronically on the publisher's internet portal (currently SpringerLink) on 21 May 2019 with open access. With the author(s)' decision to step back from Open Choice, the copyright of the article changed on 20 December 2019 to (c) Korean Society for Horticultural Science 2019, and the article is forthwith distributed under the terms of copyright. The original article has been corrected.
Publisher's Note Springer Nature remains neutral with regard to jurisdictional claims in published maps and institutional affiliations.

The original article can be found online at https://doi.org/10.1007/ s13580-019-00131-x.

Nebahat Sari

nesari@cu.edu.tr

1 Zanzibar Agricultural Research Institute, P.O. Box 159, Miwani Rd, Kizimbani, Zanzibar, Tanzania

2 Faculty of Agriculture, Department of Horticulture, Cukurova University, 01330 Adana, Turkey 